\title{
SOME PALMS IN THE MIOCENE OF THE LOWER RHENISH PLAIN
}

\author{
J. VAN DER BURGH
}

Laboratory of Palaeobotany and Palynology, State University, Heidelberglaan 2, Utrecht (The Netherlands)

(Received and accepted October 7,1983 )

\begin{abstract}
Van der Burgh, J., 1984. Some palms in the Miocene of the Lower Rhenish Plain. Rev.

Palaeobot. Palynol., 40:359-374.

Two types of palm leaves, one of them still in connection with petioles and stems, are described. These are Sabal maior Unger and a new species. For the former species additional anatomical evidence has been collected with regard to its taxonomic position and a reconstruction made.

\section{INTRODUCTION}

In the open-cast mine "Zukunft West" at Eschweiler (Federal Germany) the lignitic coal-seam "Frimmersdorf"' is locally covered by a formation of white, mainly aeolian sands. Certain horizons within this deposit have been cemented to form an initially crumbly sandstone which on exposure to air becomes so hard, that it has to be removed by blasting. This study is based upon two collections made in the sand and in the sandstone respectively.
\end{abstract}

\section{MATERIAL AND METHODS}

During the summer of 1979 two stems of palms with petioles attached were collected in the white sands overlying the Frimmersdorf seam of the main lignite. These white sands show remains of thin soils at different levels (Plate I, 1, 3; Plate II, 1; Plate IV, 1) and as whole can be interpreted as an aeolian dune deposit, i.e. beds with an undulating surface and a highly uniform grain size, at least in the upper part. The plants themselves did not root in the sand but in the underlying peat of the lignite seam. In the sand adjacent to the top of the stems there were cross-sections of the petioles and of the leaves. The former have a triangular shape, the latter form continuous zigzag lines, which indicate fan-shaped leaves (Plate I, 2, 3). Due to the disintegration of the material it proved impossible to collect the leaves or the stem material as a whole. Only some remains of the central cylinder of the smaller branched stem were preserved whereas material of the leaf sheaths could be collected from both stems. The material was included in 
the collections of the Laboratory of Palaeobotany and Palynology, Utrecht, under number 13826 (large stem) and 13827 (small stem). Thin sections of the central cylinder, the epidermis and internal tissues of the petioles were prepared.

In August 1982, Mr Köditz, engineer at "Zukunft West", informed the author of the occurrence of palm-like leaf impressions in lumps of sandstone from the same horizon. During subsequent collecting, costapalmate leaves and fragments of pinnate leaves were found. Due to the very brittle condition of the sandstone, only fragments of the pinnate leaves could be collected and it proved impossible to secure adequate photographs. The fragmentary material has been entered in the collections of the Laboratory of Palaeobotany and Palynology, Utrecht, under the numbers 13822 to 13825 and 13828 to 13836 . Cuticle preparations were made from these leaf impressions. The majority of the material came from one species, Sabal maior Unger, and enabled a study of its anatomy and morphology and the preparation of a reconstruction of the sterile plant. The other species is as yet very imperfectly known, so that it proved impossible to identify it accurately.

IDENTIFIED MATERIAL

Sabal maior Unger (Plate I-VI; Fig.1)

\section{Description}

Leaf impressions (Coll. No. 13822-13824, 13828, 13830)

General shape: The longest segment measured was $52 \mathrm{~cm}$; in this case the base as well as the tips of the leaf segments are lacking (Plate II, 4). Other impressions contain the base with a shortened rachis and numerous basically united leaf segments (ca. 35-45 segments), which form a ribbed disc with a probable length of $40-60 \mathrm{~cm}$ (Plate II, 1,3). From this a costapalmate leaf with a diameter of $90-150 \mathrm{~cm}$ can be deduced. No traces of a hastula were observed, therefore it cannot have been conspicuous.

Cuticle: The cuticle, though very brittle, was rather easy to prepare. It shows rather narrow intercostal fields and still narrower costal fields. The shape of the stomata and the general appearance are similar to the material described by Weyland (1959).

Petiole (Coll. No. 13826, 13827)

General shape: The petioles are triangular in cross-section, the longest side being $6-8 \mathrm{~cm}$, while the other two sides are $4-5 \mathrm{~cm}$ wide (Plate I, 4,5 ). No trace of any armature has been observed. At their base the petioles broaden into flat, sometimes torn sheaths. There was no abscission of the petioles of the dead leaves, so the stem was covered with sheaths and the proximal parts of the petioles, with thick mats of rootlets between (Plate III, 2). Anatomy: The vascular bundles are diffuse with little or no concentration towards the exterior. The vascular bundles contain a proto- and metaxylem, 
the latter consisting of some tracheids and up to five vessels arranged either in a row or in a cluster. The phloem is divided into two parts by fibrous tissue (Plate V, 1). A very thin sheath of fibers (2-3 cells thick) is present on the side of the phloem, the walls of which are scarcely thickened. Epidermis: No cuticle could be obtained from the petiole. It was apparent from thin sections of the dermal layers that in a number of petioles no epidermis was preserved: the suberised internal parenchyma was in direct contact with the external environment. In other cases an epidermis and hypodermis were present. The numerous stomata in this epidermis are similar to those of the leaf impressions.

Stem (Coll. No. 13827)

General shape: The stems are short, ca. $1 \mathrm{~m}$ in the larger specimen, ca. $50 \mathrm{~cm}$ in the smaller branched specimen. The stem is covered by leaf sheaths (Plate III, 3; Plate VI, 5) and in the lower part these are covered by fibrous roots, which form a conical stem base (Plate IV, 1).

Central cylinder: The central cylinder is narrow, $5-7 \mathrm{~cm}$ in diameter at the most. The cortical region is thick, up to $1 \mathrm{~cm}$. The central part is only slightly different from the peripheral part of the central cylinder. The vascular bundles are a little more crowded and the fibrous bundles are lacking in the peripheral part. The vascular bundles are similar throughout the central cylinder; they contain a protoxylem and a metaxylem with up to six vessels, which are rather narrow and often flattened against one another (Plate V, 2). The vessels have scalariform perforations with five to eight bars. These bars are ca. $2 \mu \mathrm{m}$ thick at intervals of $5-12.5 \mu \mathrm{m}$. The pits are scalariform and measure 3-5 $\times 5-15 \mu \mathrm{m}$ (Plate $\mathrm{V}, 3,5$ ). The phloem forms a band opposite the metaxylem and is capped by a sheath of fibers almost as large as the remaining part of the bundle (Plate $V, 2$ ). The fibers are thin-walled. On the outside numerous stegmata with globose, spinulous lumina are present; the diameter of the lumen is $12 \mu \mathrm{m}$ (Plate $\mathrm{V}, 4$ ). In addition to the abovedescribed vascular bundles, some very small vascular bundles and some fibrous bundles are present (Plate V, 6, 7).

\section{Identification}

The stem and the petioles have been found in organic connection. Although the leaves could not be collected due to the crumbly nature of the sediment, they were seen to be fan-shaped. On the other hand, the leaf impressions were attached to impressions of triangular, unarmed petioles, in every respect comparable to those attached to the stems. The epidermal structures, as revealed by cuticle preparations and thin sections, are similar in both petioles and leaves. Therefore, we may assume that the stems and leaf impressions originated from the same type of plant. The leaves can be identified as Sabal maior on the basis of their costapalmate morphology and the structure of the cuticle which are similar to material described by Weyland (1959). 


\section{PLATE I (p. 363)}

\section{Sabal maior Unger}

1. Top of stem no. 13827 , petioles and leaves in dune sand with thin soil horizons. $\times 0.15$.

2. A cross-section of a palmate leaf in the sand. $\times 0.2$.

3. Palmate leaves in the sand, detail of fig. $1 . \times 0.5$.

4. Cross-section of a petiole (with a large, partly filled hole made by a boring animal), no. $13826 \mathrm{~B} . \times 0.5$.

5. The abaxial side of a petiole, no. $13826 \mathrm{~N} . \times 0.5$.

PLATE II (p. 364)

Sabal maior Unger

1. Impression of a costapalmate leaf in a sandstone. $\times 0.2$.

2. Cross-section through a group of petioles. $\times 0.25$.

3. Costapalmate leaf impressions in sandstone, no. $13825 \mathrm{~A} . \times 0.15$.

4. The longest pinnae, fragment of a costapalmate leaf, no. $13825 \mathrm{H} . \times 0.15$.

\section{PLATE III (p. 365)}

Sabal maior Unger

1. Two plants in the sand. $\times 0.04$.

2. Leaf-base sheaths with intervening rootmats, no. $13826 \mathrm{~A} . \times 0.4$.

3. Leaf bases around the central cylinder, view from the interior, no. $13827 \mathrm{~B} . \times 0.4$.

PLATE IV (p. 366)

Sabal maior Unger

1. The large stem of Plate III, 1 with its thick fibrous base. $\times 0.15$.

PLATE V (p. 367)

Sabal maior Unger

1. Vascular bundle in petiole, no. 13826B. $\times 400$.

2. Vascular bundles in the central cylinder of the stem, no. $13826 . \times 100$.

3. Scalariform pitting in the vessel walls, no. $13826 . \times 400$.

4. Stegmata, no. 13826. $\times 400$.

5. Scalariform vessel perforation, no. $13826 . \times 400$.

6. Fibrous bundle, no. $13826 . \times 100$.

7. Small vascular bundle, no. $13826 . \times 100$.

PLATE VI (p. 368)

1, 2. Cuticle of Sabal maior, prep. C 506. $1, \times 400,2, \times 100$.

3,6 . Cuticle of Chamaerops humilis, prep. 454. $3, \times 400 ; 6, \times 100$.

4, 7. Cuticle of Sabal palmetto, prep. 450. 4, × 400; 7, × 100 .

5. Sabal maior, leaf bases seen from the exterior, no. $13827 \mathrm{~A} . \times 0.3$.

\section{PLATE VII (p. 369)}

Palmae gen. et sp. indet.

1. Fragment of a pinnate leaf, no. 13836 . $\times 0.4$.

2. Fragment of a pinnate leaf, no. 13829. $\times 0.3$.

4. Fragment of a pinnate leaf, no. 13835. $\times 0.3$.

$3,5,6$. Cuticle, prep. C $512 . \times 400$. 
PLATE I
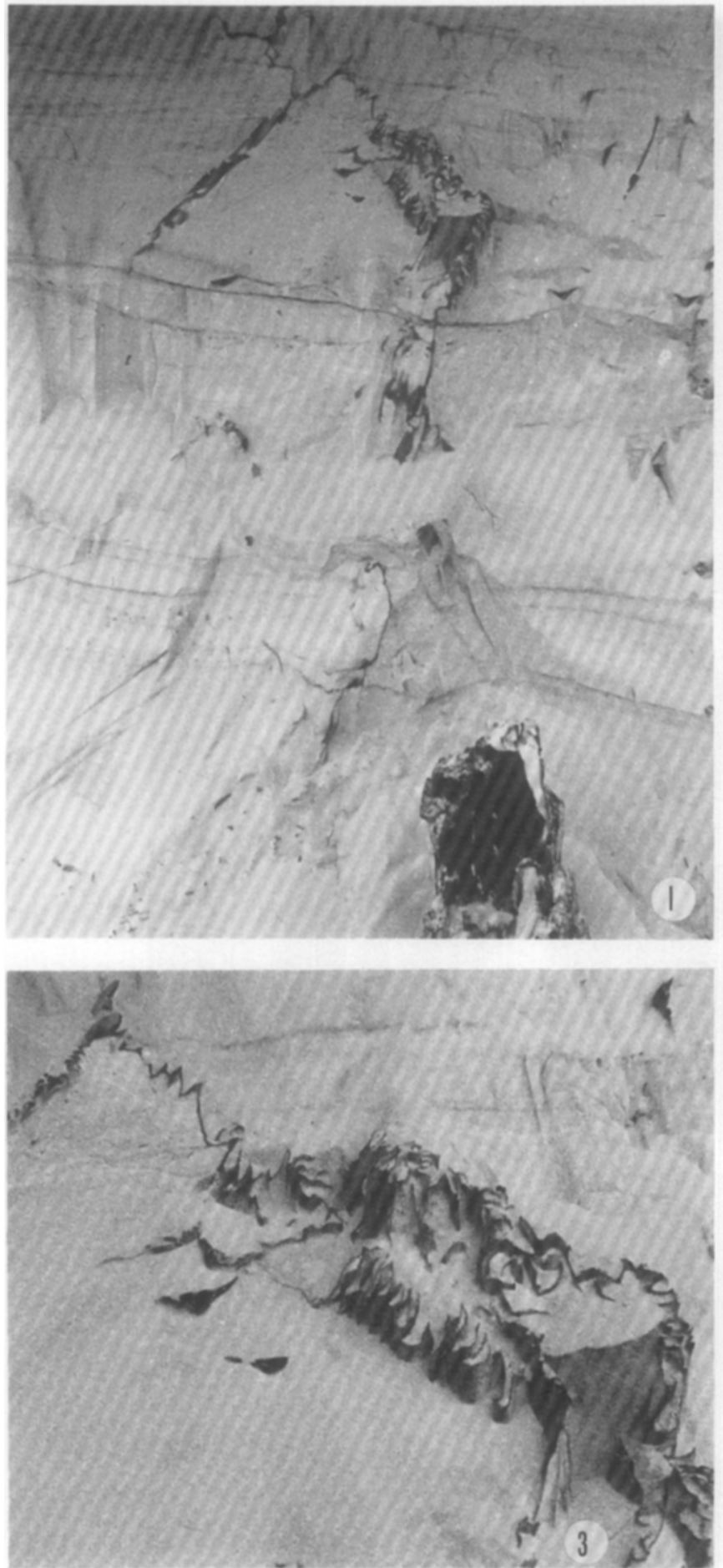

Description on p. 362
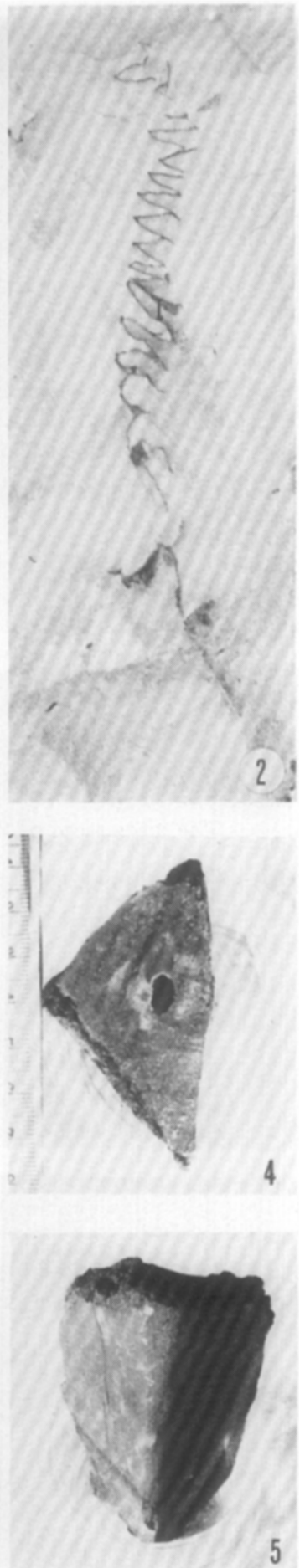

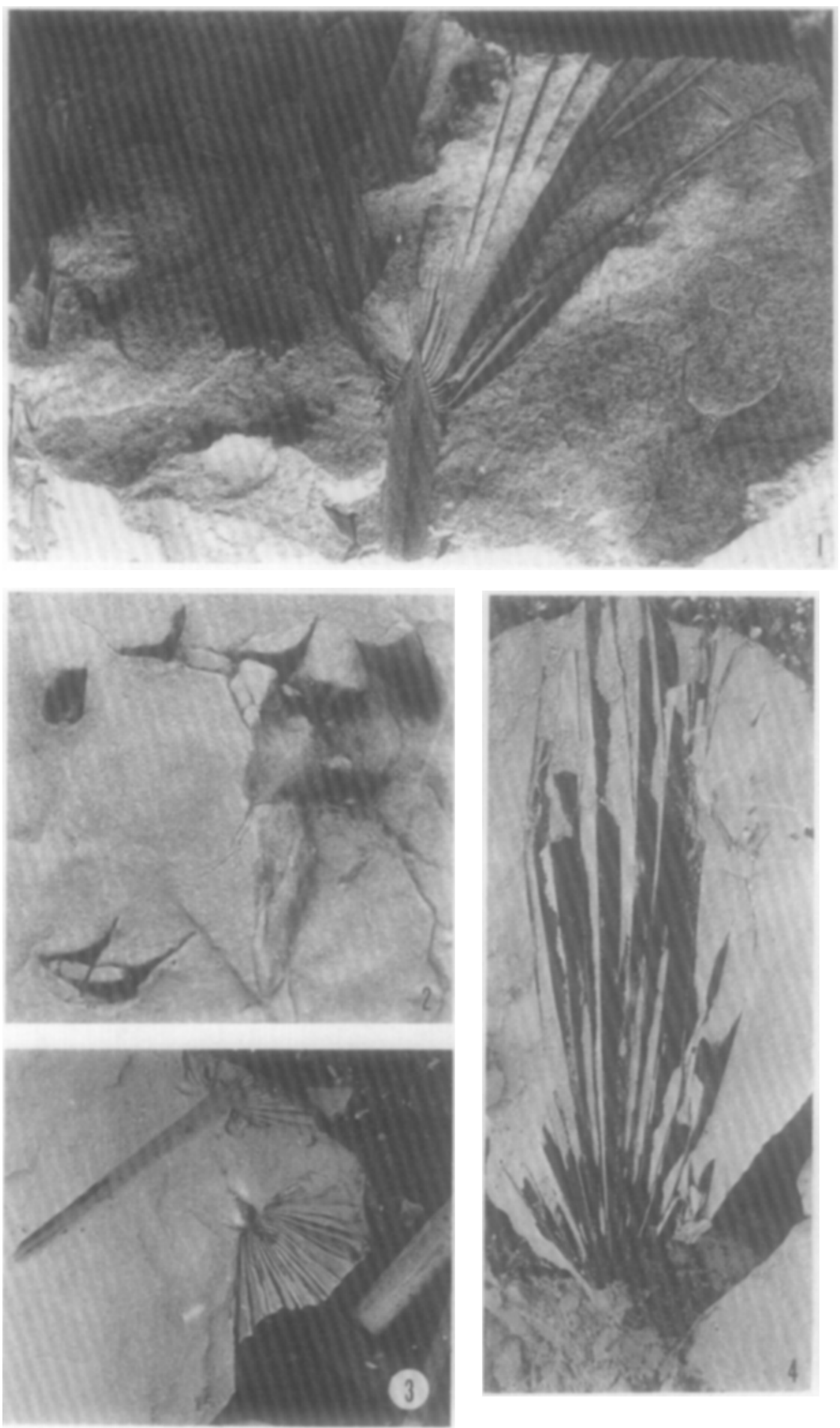

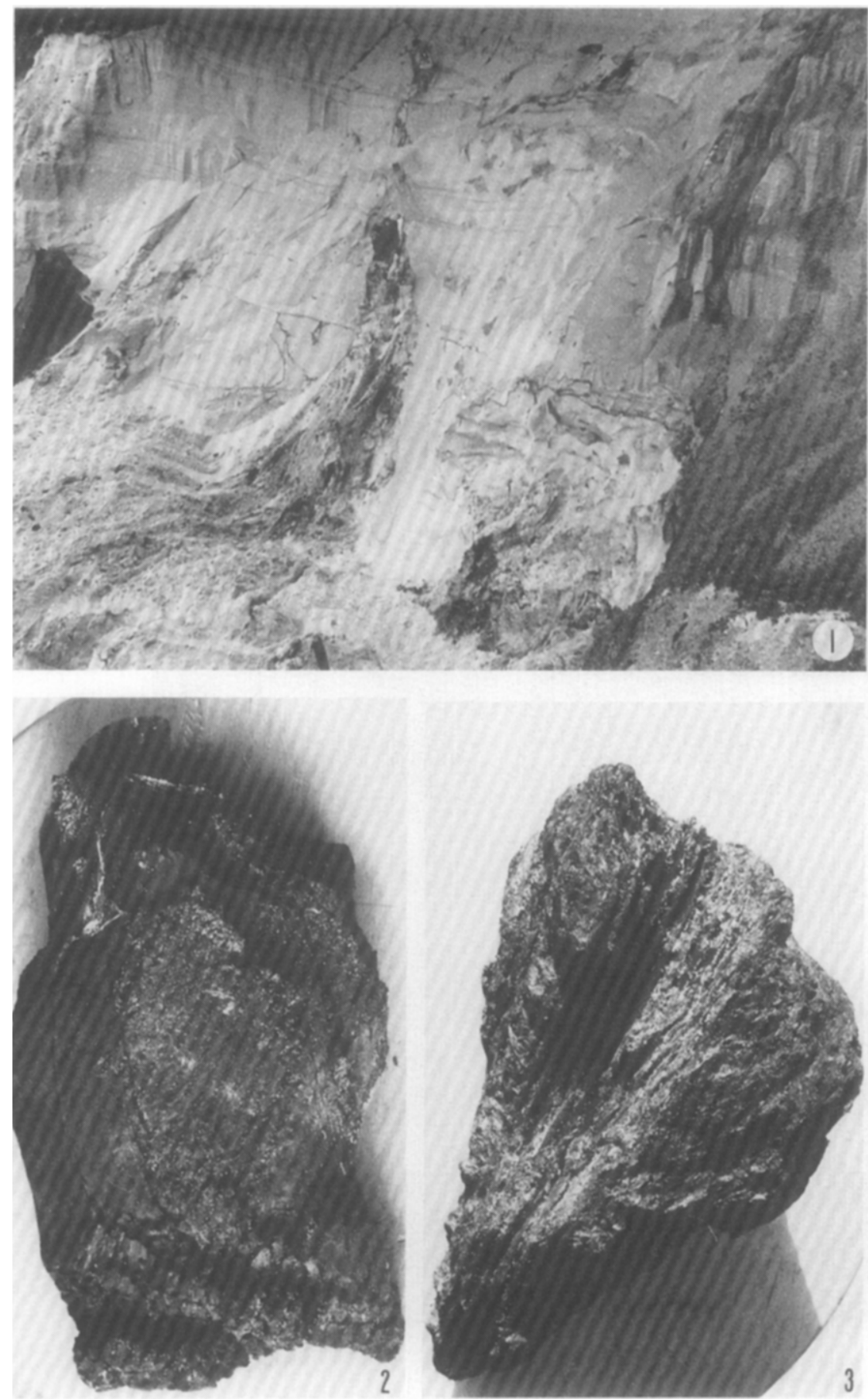


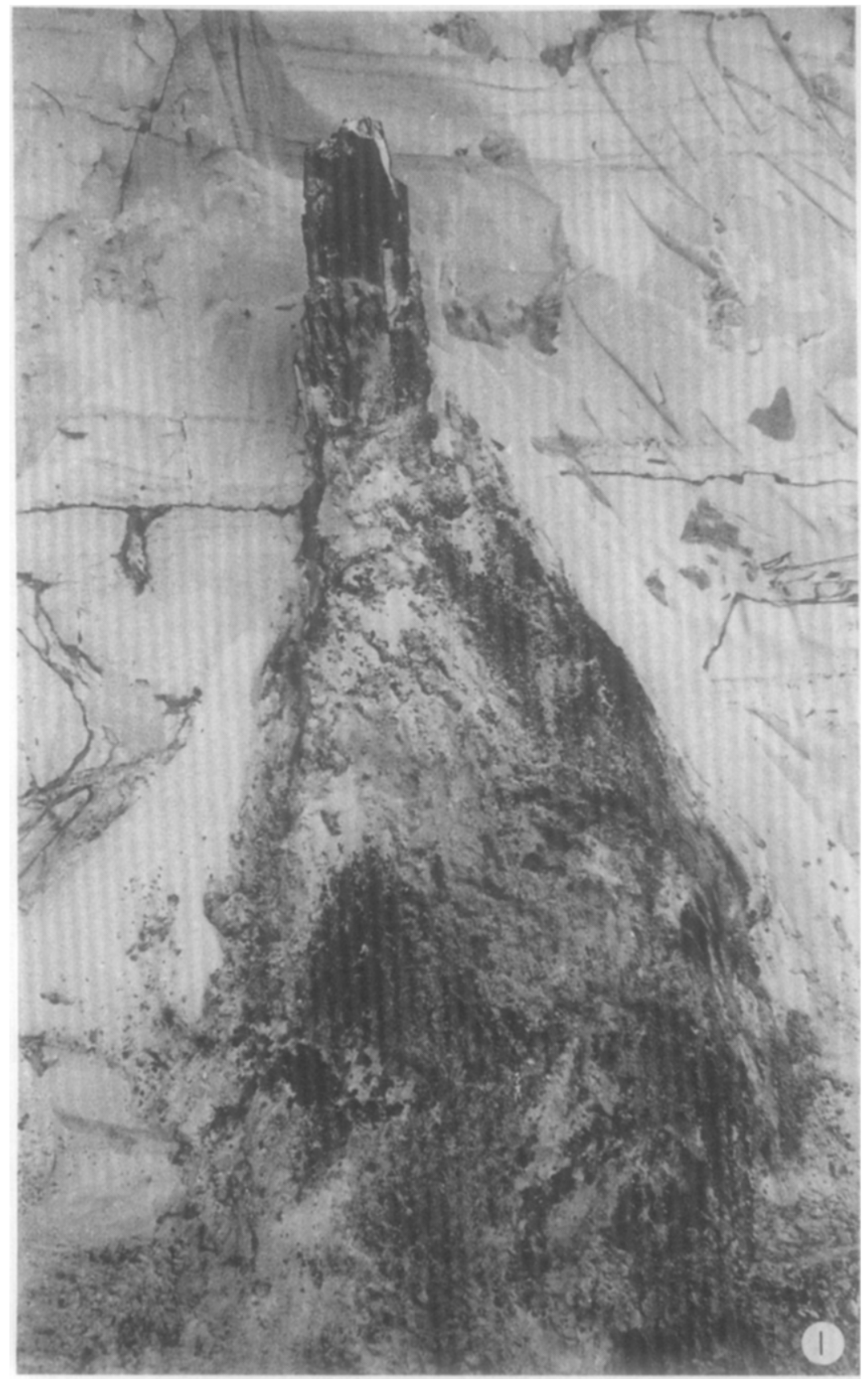




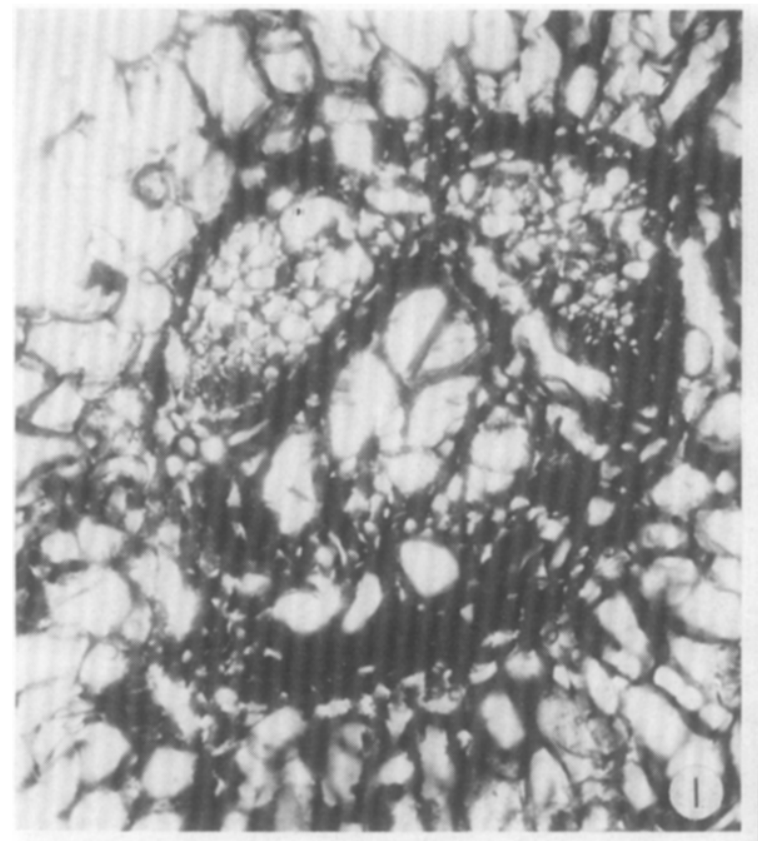

was.

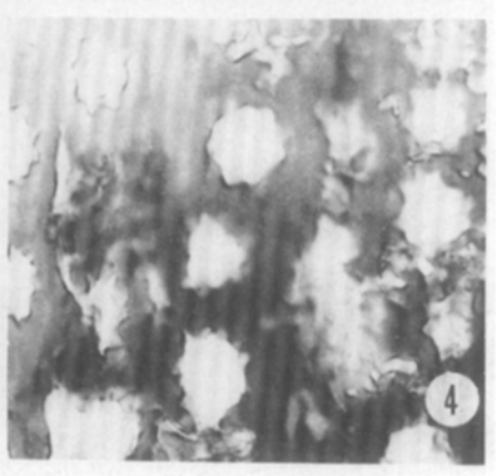

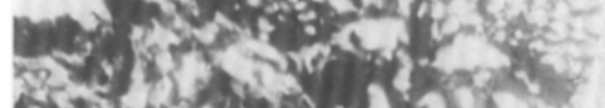

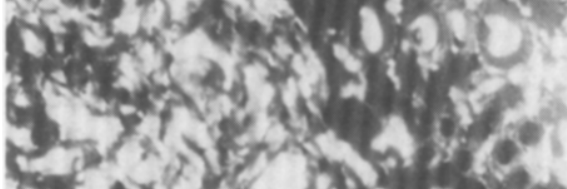

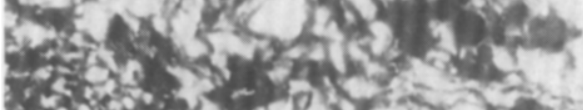

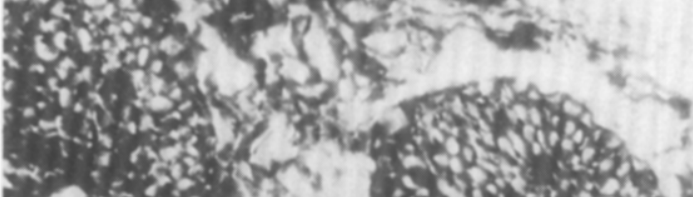

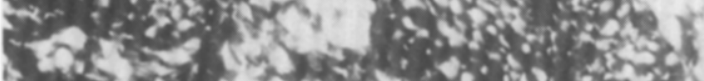

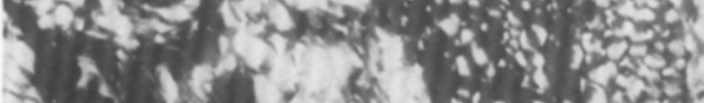

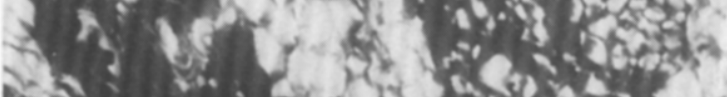

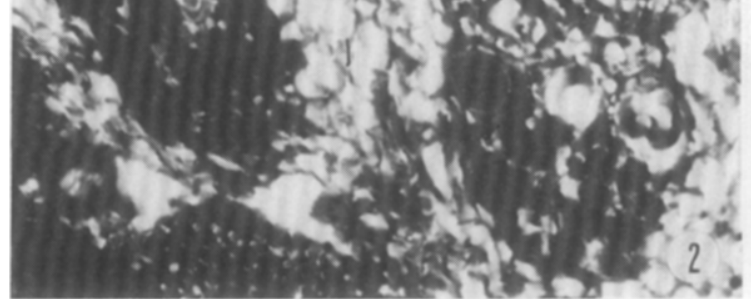
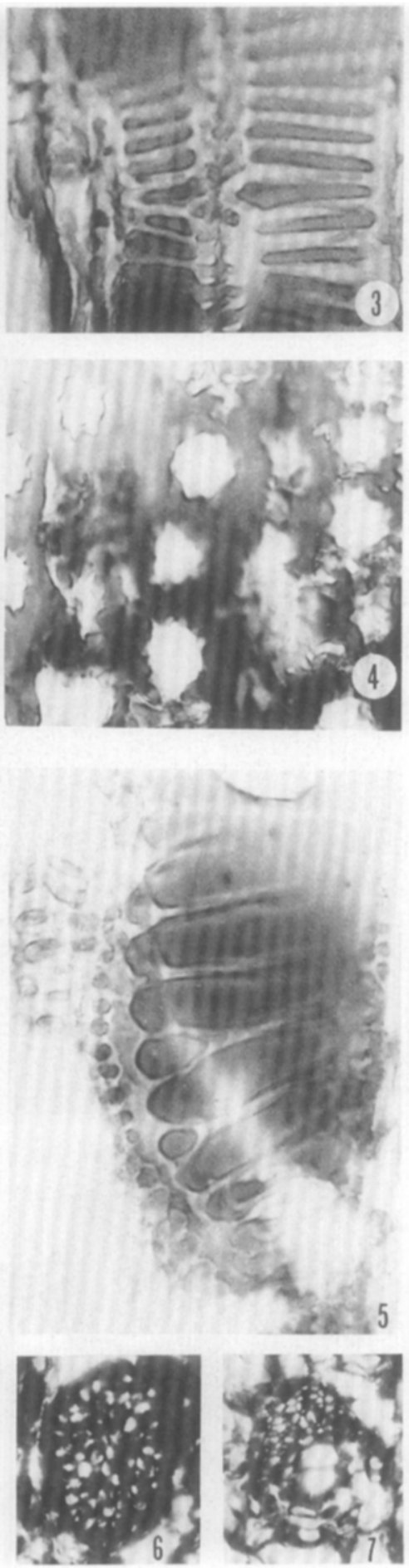


\section{PLATE VI}
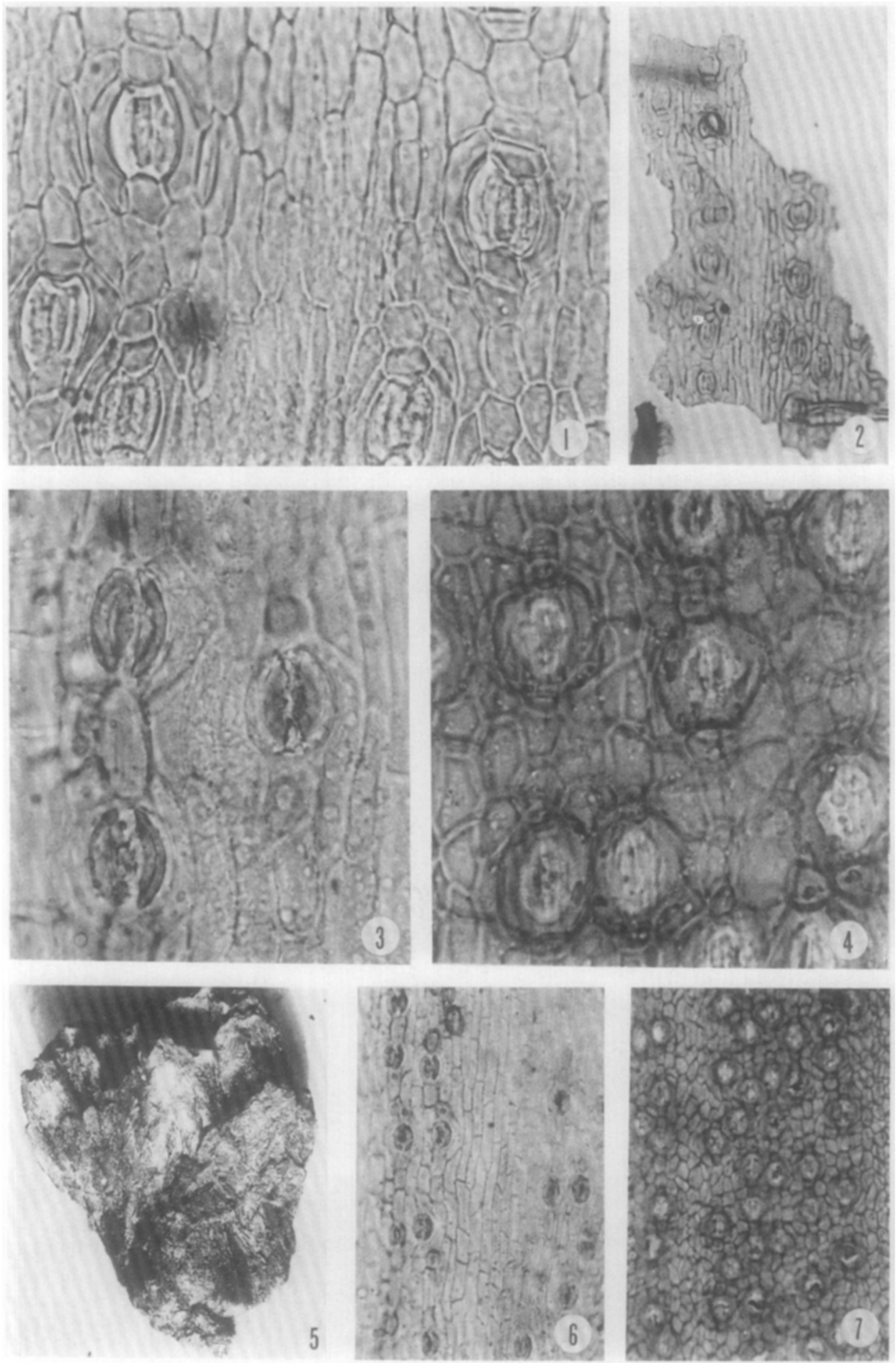
PLATE VII

Description on p. 362
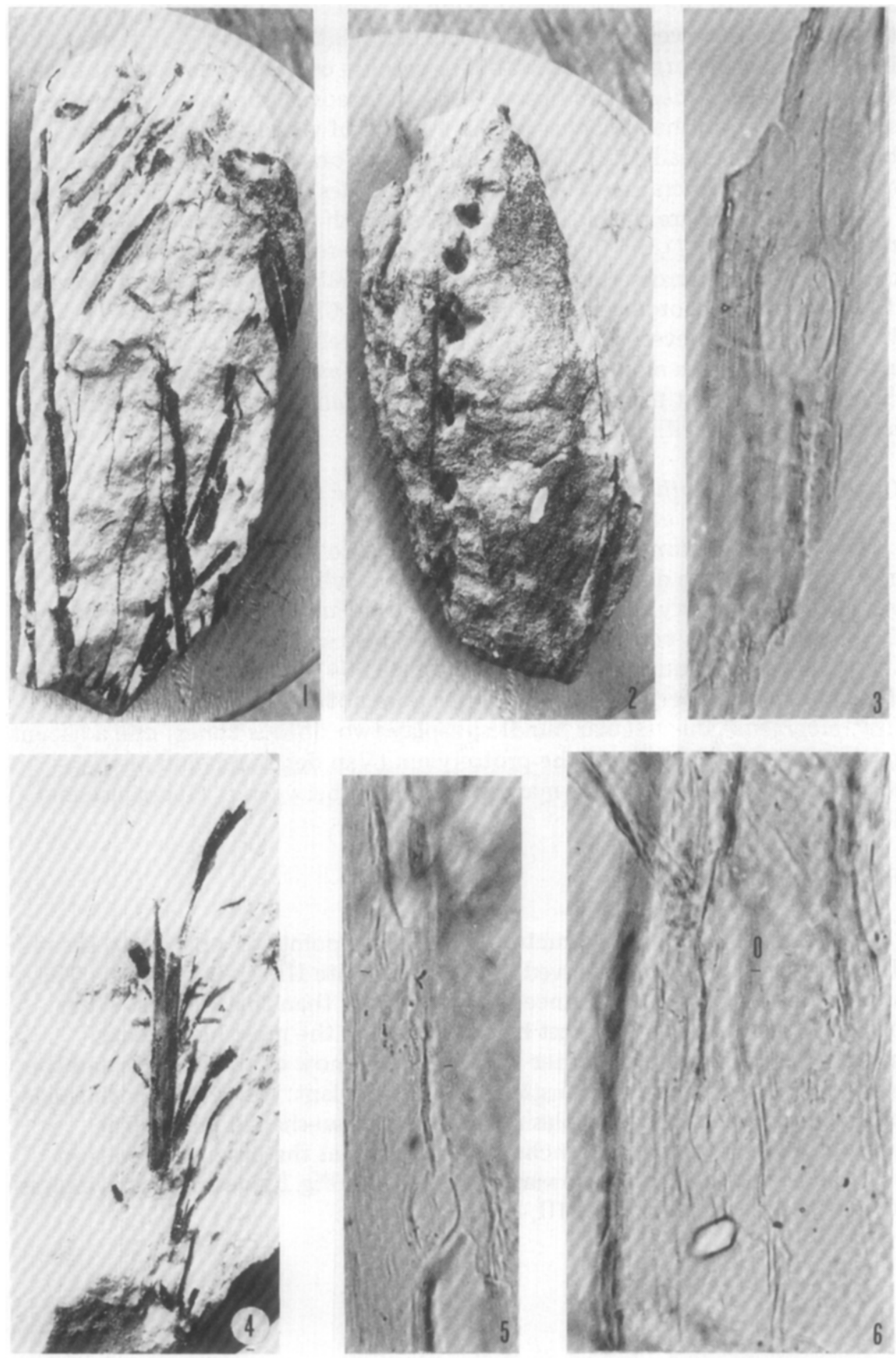
The morphology and the structure of the epidermis of the petioles are in accordance with the above identification as a species of the genus Sabal; the anatomy however is different. In the petioles the anatomy of the vascular bundles shows an organisation with two patches of phloem instead of three, such as in recent Sabal (Tomlinson, 1961). Moreover, the anatomy of the stem differs from that of $S a b a l$ by the number of vessels in the vascular bundles ( $3-6$ instead of 2 ), the scalariform perforations of the vessels and by the thin-walled fibers next to the vascular bundles (Tomlinson, 1961).

When we compare the cuticle of the fossil with that of modern Sabal (Plate VI, 1, 2, 4, 7), we find differences: in the fossil species the intercostal fields are narrower, and their epidermal cells somewhat more elongate. This is more in accordance with the situation in Chamaerops (Plate VI, 3, 6). In this genus, however, the terminal subsidiary cells of the stomatal complex are somewhat more elongated. Therefore, Sabal maior is in some major characters different from the recent species of Sabal and occupies a rather isolated position within the genus.

\section{Comparison with other palm-like fossils from the same region}

The general anatomy and morphology point to a palmetto shrub (thick cortex, no sclerotic dermal zone in the central cylinder, relatively narrow vessels in the metaxylem). This is also found in Palmoxylon bacillare and $P$. eibergense. In $P$. bacillare, however, the fibers are thick-walled and the stegmata are less numerous (Van der Burgh, 1964). As pointed out by Weyland and Kilpper (1964) this species does not in fact represent a palm. In $P$. eibergense the vascular bundles display two fibrous zones: one adjacent to the phloem, the other to the protoxylem (Van der Burgh and Meulenkamp, 1966). There is thus a marked difference between $P$. eibergense and the present fossil.

\section{Reconstruction}

As remarked above, the structure of the stem points to a palmetto shrub. This is what was in fact observed in the sand (Plate III, 1; Plate IV, 1). The stem is poorly lignified and since it is less woody than that of most other palmetto palms, this palm must be considered as the most herbaceous member of the family. Together with what we know of the petioles and the leaves, this enables us to reconstruct the sterile plant: low shrubs with single or branched stems, long petioles and enormous fan-shaped leaves. The petioles of the horizontal branches were twisted at the base, so as to turn the adaxial side of the leaf upwards (Plate II, 2). Fig.1 gives an artist's impression of the plants from Plate III, 1. 


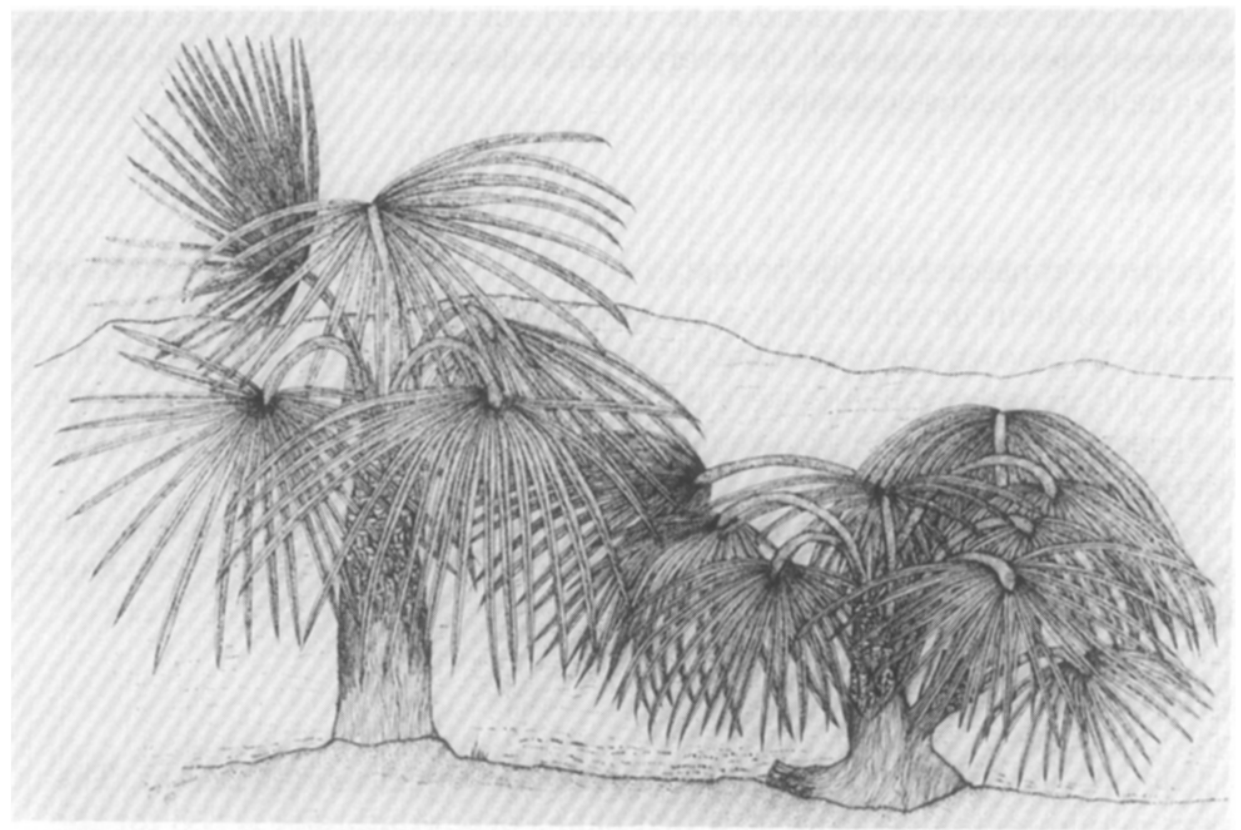

Fig.1. Reconstruction of Sabal maior Unger.

Palmae gen. et sp. indet. (Plate VII, 1-6)

\section{Description}

General shape (Coll. No. 13829, 13831-13836)

Only the leaves of this palm have been collected. Leaves pinnate, leaflets reduplicate, at intervals of $2-3 \mathrm{~cm}$, forming an angle of about $30-35^{\circ}$ with the rachis. The rachis which is ca. $1 \mathrm{~cm}$ across, is quadrangular in crosssection and has a sharp keel. No armature has been observed. The leaflets are $0.8-1.2 \mathrm{~cm}$ wide, their length is unknown, the longest fragment being $18 \mathrm{~cm}$ (Plate VII, 1, 2, 4).

Cuticle: The cuticle is extremely thin and fragile, with stomata in a single row in the very narrow intercostal fields, separated by still narrower costal fields. The stomata have elongated subsidiary cells. The walls of the epidermal cells are straight, the cells of the intercostal fields are elongate, those in the costal fields somewhat irregular (Plate VII, 3, 5, 6).

Remarks: Similar stomata, very narrow intercostal fields and pinnate leaves are known for example from lepidocaroid palms, to which Calamus, Daemonorops, etc., belong. These palms, however, are characterised by an epidermis with sinuous cell walls, while the above material has straight anticlinal cell walls. Kräusel and Weyland (1954) and Mai (1964) described some cuticles with straight walls belonging to Calamus; but these cuticles differ from the above material in the shape of the cells and the stomata. The 
material described by Weyland et al. (1966) with its armed petioles is again different from our material. Our very scanty data make it impossible to identify the leaf remains accurately.

\section{ECOLOGY}

In the reconstruction the palmetto shrubs are pictured in a dune landscape, the environment in which they were actually found. However, leaves and cuticles are known from the lignite (Kräusel and Weyland, 1954; Weyland, 1957,1959 ) and our plants were in fact rooted in the underlying peat, not in the sand of the dunes. So, we may assume that they required moist conditions.

Of the second species nothing is known except that it was found in the same dune sandstone as the first species. It is as yet impossible to say anything about the ecology of this palm.

\section{CLIMATIC IMPLICATIONS}

The presence of palms has some far-reaching climatic implications. The mean minimum temperature at which palms occur naturally is $8^{\circ} \mathrm{C}$ for the coldest month and the mean annual temperature must be $12^{\circ} \mathrm{C}$ or more. The reconstruction of the climate of the Rhenish lignite by Van der Burgh (1973) was based upon the occurrence of (a) palms, (b) Picea or Larix on peat, (c) Sequoia, (d) the percentage of leaf impressions with entire margins in floras of comparable age, and (e) the climate of that part of Western Europe where comparable species can be grown. One of the two palms described here belongs to the sabaloid palms, a group to which the most northerly genera Trachycarpus, Chamaerops, Sabal and Serenoa belong. Thus, it is not necessary to invoke a much higher mean temperature for the warmest month $\left(22^{\circ} \mathrm{C}\right.$ in the reconstruction of Van der Burgh, 1973). Even a mean temperature higher than $6^{\circ} \mathrm{C}$ for the coldest month is questionable, for Trachycarpus can easily be grown in regions with such a minimum temperature for the coldest month: in fact it can be grown in maritime France, Great Britain (as far northly as northwestern Scotland) and Ireland. The other palm, however, is an unknown factor and it is possible that it belongs to a much more tender group of palms. The flora of Kreuzau, which is of comparable age, contains $47 \%$ leaves with entire margins (Ferguson, 1971). Van der Burgh (1973) suggested a climate with a mean annual temperature of $11-16^{\circ} \mathrm{C}$, a mean temperature of the warmest month of $22-27^{\circ} \mathrm{C}$, a mean temperature of the coldest month of at least $3^{\circ} \mathrm{C}$, a temperature difference of ca. $20^{\circ} \mathrm{C}$, while precipitation must have been at least $1000 \mathrm{~mm}$ annually. Our material has been found in a series of deposits which according to the fossil flora (such as Mastixioideae) belongs to zone VI of Mai (1967). For this zone, which Mai characterised as subtropical, he gave the following climatic data: a mean annual temperature of $20-23^{\circ} \mathrm{C}$, a temperature difference of $7-20^{\circ} \mathrm{C}$, a precipitation of $1000-2000 \mathrm{~mm}$ and a minimum temperature above $0^{\circ} \mathrm{C}$. 
Mai (1967) suggested a mean annual temperature for his youngest Mastixioideae floras (Zone $\mathrm{X}$ and XII) of 18.2 and $16.9^{\circ} \mathrm{C}$ respectively, with a mean temperature of the warmest month of respectively 20.6 and $22.7^{\circ} \mathrm{C}$ and a mean temperature of the coldest month of 14.4 and $12.1^{\circ} \mathrm{C}$ while the precipitation was judged to be 2300 and $2600 \mathrm{~mm}$ annually. Van der Burgh (1973) suggested a mean annual temperature of $12^{\circ} \mathrm{C}$, with a mean temperature of the warmest month of $22^{\circ} \mathrm{C}$ and a mean temperature of the coldest month of $6^{\circ} \mathrm{C}$, while precipitation must have been at least $1000 \mathrm{~mm}$ annually. In this reconstruction the mean temperature difference between the coldest and warmest month is $16^{\circ} \mathrm{C}$, which is rather high for a subtropical climate. The question is whether the climate of the Miocene was subtropical at all during its warmer periods, or in other words: Is it correct to describe a palaeoclimate in terms of the recent climate, since this differs from the Tertiary palaeoclimate in its very pronounced extremes (cold-heat, dry-wet)? The fact is that the palaeoenvironment was very different from the recent situation: The temperature of the North Sea was high and its surface area considerably greater, while the mountains in the vicinity were comparatively low with the exception of some small volcanoes. All these data suggest a more equable climate with little difference between winter and summer, both in temperature and precipitation, with much cloud and precipitation annually - that is, what we now would term an extremely oceanic climate. It is clear that while the presence of some palaeotropical genera has been used as an argument for accepting a high annual temperature, the large number of conifers, even during the warmest periods, suggests that the mean annual temperature cannot have been all that high.

Since the climate of the present-day habitat may not represent the full range of climatic tolerance or because the requirements of a particular taxon may have changed, any palaeoclimatic reconstruction is to some extent an approximation. A number of relevant climatic data are summarised in Table I.

\section{TABLE I}

Comparison of some Miocene and recent climatic data

\begin{tabular}{|c|c|c|c|c|c|}
\hline & $\begin{array}{l}\text { Mean annual } \\
\text { temperature } \\
\left({ }^{\circ} \mathrm{C}\right)\end{array}$ & $\begin{array}{l}\text { Warmest month } \\
\text { mean tempera- } \\
\text { ture }\left({ }^{\circ} \mathrm{C}\right)\end{array}$ & $\begin{array}{l}\text { Coldest month } \\
\text { mean tempera- } \\
\text { ture (C) }\end{array}$ & $\begin{array}{l}\text { Temperature } \\
\text { difference } \\
\left({ }^{\circ} \mathrm{C}\right)\end{array}$ & $\begin{array}{l}\text { Precipita- } \\
\text { tion } \\
(\mathrm{mm})\end{array}$ \\
\hline $\begin{array}{l}\text { Miocene of } \\
\text { Kreuzau } \\
\text { (Van der Burgh, 1973) }\end{array}$ & $11-16$ & $22-27$ & $\geqslant 3$ & ca. 20 & $\geqslant 1000$ \\
\hline $\begin{array}{l}\text { Extant Sequoia } \\
\text { (Van der Burgh, 1973) }\end{array}$ & $11-15$ & $\leqslant 23$ & 6 & ca. 16 & $\geqslant 640$ \\
\hline $\begin{array}{l}\text { Piced and Larix } \\
\text { on peat at present day } \\
\text { (Van der Burgh, 1973) }\end{array}$ & $1-8$ & 22 & $\leqslant 0$ & ca. 22 & $\geqslant 1000$ \\
\hline $\begin{array}{l}\text { Extant Palmae } \\
\text { (Van der Burgh, 1973) }\end{array}$ & 12 & & $\geqslant 8$ & ca. 4 & \\
\hline $\begin{array}{l}\text { Zone VI } \\
(\text { Mai, 1967) }\end{array}$ & $20-23$ & & $>0$ & $7-20$ & $1000-2000$ \\
\hline $\begin{array}{l}\text { Zone X } \\
\text { (Mai, 1967) }\end{array}$ & 18.2 & 20.6 & 14.4 & 6.2 & 2300 \\
\hline $\begin{array}{l}\text { Zone XII } \\
\quad(\text { Mai, 1967) }\end{array}$ & 16.9 & 22.7 & 12.1 & 10.6 & 2600 \\
\hline
\end{tabular}


It seems likely that the mean annual temperature was about $14^{\circ} \mathrm{C}$, otherwise the situation would become impossible for the conifers growing on peat. One may infer a mean temperature for the warmest month in the order of $18^{\circ} \mathrm{C}$, a mean temperature for the coldest month of about $10^{\circ} \mathrm{C}$ and a mean annual difference of $8^{\circ} \mathrm{C}$. The precipitation was high, probably in the order of $1500-2500 \mathrm{~mm}$ annually.

\section{ACKNOWLEDGEMENTS}

The author wishes to thank the board of the Rheinische Braunkohle A.G. for permission to collect and Ir Nehring and Ir Kothen and the Staffdivision B 41 of the "Rheinbraun" for their help. Thanks are due to the Staff at the open-cast mine "Zukunft West", especially Markscheider Ir Stahl and Ir Köditz. The author is especially indebted to Dr D.K. Ferguson for reading, criticising and improving the English text. Furthermore, he wishes to thank Mr J. van Zeitveld for drawing the reconstruction reproduced as Fig.1.

\section{REFERENCES}

Ferguson, D.K., 1971. The Miocene flora of Kreuzau, Western Germany, 1. Verh. K. Ned. Akad. Wet., Afd. Nat., 2e Reeks, 60(19): 1-279.

Kräusel, R. and Weyland, H., 1954. Kritische Untersuchungen zur Kutikularanalyse tertiärer Blätter II. Palaeontographica, B 96: 106-163.

Mai, D.H., 1964. Die Mastixioideenfloren im Tertiär der Oberlausitz. Paläontol. Abh., 2: 1-192.

Mai, D.H., 1967. Die Florenzonen, der Florenwechsel und die Vorstellungen über den Klimaablauf im Jungtertiär der Deutschen Demokratischen Republik. Abh. Zentr. Geol. Inst., 10: 55-81.

Tomlinson, P.B., 1961. Anatomy of the Monocotyledons II. Palmae. Oxford University Press, Oxford, $453 \mathrm{pp}$.

Van der Burgh, J., 1964. Hölzer der Niederrheinischen Braunkohlenformation, I. Hölzer der Braunkohlengrube "Anna" zu Haanrade (Niederländisch Limburg). Acta Bot. Neerl., 13: 350-401.

Van der Burgh, J., 1973. Hölzer der Niederrheinischen Braunkohlenformation, II. Hölzer der Braunkohlengruben "Maria Theresia" zu Herzogenrath, "Zukunft West" zu Eschweiler und "Victor" (Zülpich mitte) zu Zülpich. Nebst einer systematisch anatomischen Bearbeitung der Gattung Pinus L. Rev. Palaeobot. Palynol., 15: 73-275.

Van der Burgh, J. and Meulenkamp, J.E., 1966. Über einige fossile palmenartige Hölzer aus den östlichen Niederlanden. Acta Bot. Neerl., 15: 276-283.

Weyland, H., 1957. Kritische Untersuchungen zur Kutikularanalyse tertiärer Blätter, III. Monocotylen der Rheinischen Braunkohle. Palaeontographica, B 103: 34-74.

Weyland, H., 1959. Kritische Untersuchungen zur Kutikularanalyse tertiärer Blätter, V. Weiteres über Monocotylen der rheinischen Braunkohle. Palaeontographica, B 106 : $1-10$.

Weyland, H. and Kilpper, K., 1964. Stammbildende Monokotylen der niederrheinischen Braunkohle. Palaeontographica, B 115: 1-20.

Weyland, H., Kilpper, K. and Berendt, W., 1966. Die Stacheln-tragende Palme der niederrheinischen Braunkohle. Palaeontographica, B 118: 74-92. 